J. Perinat. Med. $16(1988) 453$

\section{Long-term hospitalization and $\beta$-mimetic therapy in the treatment of intrauterine growth retardation of unknown etiology}

\author{
Luis Cabero, Maria José Cerqueira, José del Solar, Jordi Bellart, and Juan Esteban- \\ Altirriba \\ Obstetrics and Gynecology Service, Santa Creu i Sant Pau Hospital, Autonomous \\ University of Barcelona, Spain
}

\section{Introduction}

Intrauterine growth retardation (IGR), is a major cause of perinatal morbidity-mortality. Its diagnosis and treatment constitutes one of the most important challenges of present day obstetrics [2].

Many factors are related to fetal development and growth; therefore, there are many reasons which may lead to low birth infants [4, 8]. A small percentage of IGR may have a maternal origin including diabetes, pregnancy-related hypertensive states and cardiopathies. In most instances the etiology of IGR is unknown.

The absence of a uniform etiology may help one understand the existence of the large number of treatments suggested for correcting the problem. This includes the lack of positive results, since IGR fetuses do not respond to solid etiopathogenic bases, but rather up on symptomatic aspects or very specific etiological factors of the disease $[4,8]$.

This report is a prospective study of the treatment of IGR of unknown etiology which is based on a long hospital stay and betamimetic drug administration.

\section{Material and methods}

A group of 98 women in the course of their third trimester of pregnancy was studied. The ultrasonographic studies performed had raised the possibility of IGR. We understand IGR to be a difference greater than two weeks between menstrual dating and ultrasonographic dating based upon biparietal diameter, cephalic area and perimeter, abdominal area and perimeter which were studied with 2 measurements performed 15 days apart. All the patients were included in a IGR screening protocol from the beginning of their pregnancy. The screening included both serial ultrasonographic studies and menstrual establishment of gestational age.

The patients were randomly assigned to the two groups. Both groups were homogeneous with regard to age, parity, previous IGR history, clinical history, food and toxic habits, and gestational age on admission and at the time of delivery.

\section{- Group A. Treatment groups: made up of 44 patients \\ - Group B. Control group: made up of 54 pa- tients.}

The size difference between groups was due to an error while transcribing the randomized lists, so that five patients which should have been assigned to the treatment group, became part of the control group. Since the error was random itself, the patients were not excluded from the study.

At the time the diagnostic suspicion was raised, the patients were admitted into our Center's High Risk Unit. Complete hematological, coagulation, biochemical and hormone level tests were performed on all patients. The biochemicaly results were normal, and a slight iron differency anemia was detected in a third of them. This was corrected with the appropiate medication. Serum tests to detect rubella, toxoplasmosis, cytomegalovirus and lysteriosis were done in order to discard any possible infectious etiology. The results were neg- 
ative in all cases. Likewise, amniocentesis was performed to evaluate fetal maturity by the Clements test and by orange cell determination as a gestational age marker. The results of these tests will be published elsewhere.

Maternal well-being studies included: determination of maternal constants, uterine activity, fetal movements and fetal heart rate, every 12 hours; uterine height, abdominal perimeter and body weight, every 24 hours; non-stress tests (NST) every 48 hours; and weekly sonographic controls along with blood and biochemical tests.

The patients from Group A remained in hospital until the end of pregnancy with a mean stay of $15 \pm 5$ days; they received Beta-mimetic treatment with ritodrine at a dose of $10 \mathrm{mg} / 8$ hours, P. O. (table I). Furthermore, they were prescribed absolute rest in bed, high caloric, high protein and high carbohydrate diet with an average caloric intake of $60 \mathrm{Kcal} / \mathrm{Kg}$ body weight per day, along with vitamin and mineral $(\mathrm{Ca}, \mathrm{Fe}$, Folic acid, vitamin $B_{12}$ ) suplements.

The patients from the Control Group were discharged following an average stay of $7 \pm 3$ days. They were prescribed home rest, high caloric diet and measurement of fetal movements twice daily. The patient was hospitalized if the number of movements was less than five in one hour. This group was not treated with ritodrine. They underwent weekly outpatient visits, where blood and biochemied tests were done. NST, and vital signs were evaluated, just as in the treatment group.

Table I.

\begin{tabular}{|c|c|c|}
\hline Group & Treatment & Control \\
\hline Mean stay & 15 days & 7 days \\
\hline Ritodrine & $10 \mathrm{mgm} / 8$ hours & no \\
\hline Control & at hospital & $\begin{array}{l}\text { out patient } \\
\text { care }\end{array}$ \\
\hline \multicolumn{3}{|l|}{ Fetal } \\
\hline movements & 12 hours & 12 hours \\
\hline FHR/UA & 12 hours & 7 days \\
\hline \multicolumn{3}{|l|}{$\mathrm{UH} / \mathrm{AC}$} \\
\hline weight & 24 hours & 7 days \\
\hline NST & 48 hours & 7 days \\
\hline Amniocentesis & 7 days & 7 days \\
\hline Echografy & 7 days & 7 days \\
\hline Analysis & 7 days & 7 days \\
\hline
\end{tabular}

FHR: fetal heart rate. UA: uterine activity. UH: uterine height. AC: abdominal circunference
Fetal weight assessment and classification in the Fetal Growth Retardation Group was decided in relation to gestational age and according to our Center's weight curve [1].

We defined acute fetal distress as the presence of a fetal $\mathrm{pH}$ value lower than 7.25 in the absence of maternal acidosis. At delivery we considered pathological any $\mathrm{pH}$ values under 7.20 when obtained from the umbilical artery.

The statistical analysis was done using the Ordered Chi square test with YATES' correction when necessary. The accepted risk alfa level was $5 \%$.

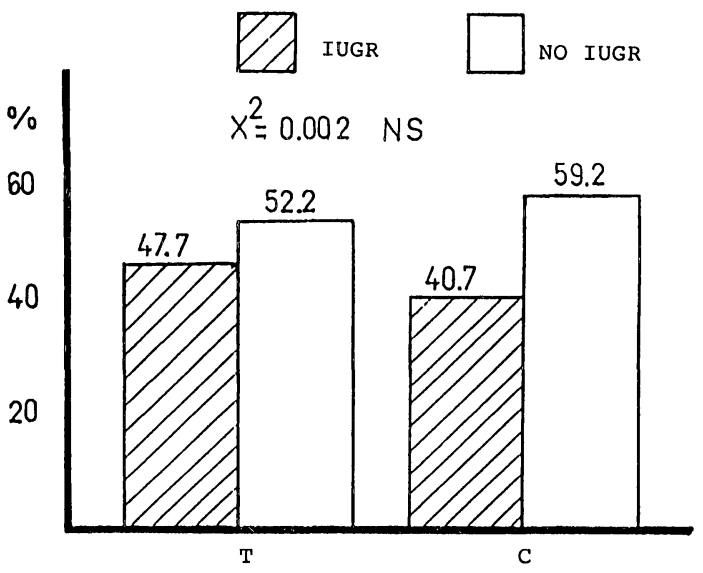

Figure 1. Prevalence of IUGR in treatment group versus control group.

\section{Results}

The prevalence of low birth weight infants for their gestational age was $47.73 \%$ ( 21 cases) in the treatment group and $40.74 \%$ (22 cases) in the control group (figure 1). The difference is not significant. Mean weights were similar in both groups: $2.903 \pm 407 \mathrm{gm}$. in group $\mathrm{A}$, and 2.886 $\pm 410 \mathrm{gm}$. in group B. The mean weight of IGR infants was $2.565 \pm 217 \mathrm{gm}$. in the treatment group and $2.504 \pm 253$ in the control group. The weight of normal newborns was $3.213 \pm 323 \mathrm{gm}$. in the first group, and $3.063 \pm 263 \mathrm{gm}$. in the second one (table II).

Of the deliveries $40.9 \%$ of labors in the treatment group were induced. Half were induced for fetal causes (cardiotocographic alterations following either NST or stress test, meconium in the amniotic fluid or lack of sonographic growth). The 
control group showed similar findings. There were $35.18 \%$ induced labors, and of these, $47.35 \%$ were due to fetal indications (table III).

Of the cases in the treatment group $18.18 \%$ were delivered by cesarean section, of which $62.5 \%$ were due to fetal distress. The control group showed similar figures: $16.66 \%$ cesarean sections with $77.7 \%$ of them due to fetal distress.

We observed an incidence of $20.45 \%$ of acute fetal distress in the study group against $12.96 \%$ in the control group. Such a difference is not statistically significant (table IV).

Table II.

\begin{tabular}{lll}
\hline & $\begin{array}{l}\text { Mean weight } \\
(\mathrm{gms})\end{array}$ & $\begin{array}{l}\text { Total } \\
\text { Mean weight }\end{array}$ \\
\hline $\begin{array}{l}\text { IUGR } \\
\text { Treatment } \\
\text { group }\end{array}$ & $2.565 \pm 217$ & $2.903 \pm 407$ \\
\begin{tabular}{l} 
No IUGR \\
\hline $\begin{array}{l}\text { IUGR } \\
\text { Control } \\
\text { group }\end{array}$
\end{tabular} & $3.213 \pm 323$ & \\
No IUGR & $2.504 \pm 253$ & $2.886 \pm 410$ \\
\hline
\end{tabular}

Table III. Type of parturition

\begin{tabular}{lll}
\hline & $\begin{array}{l}\text { Treat- } \\
\text { ment }\end{array}$ & Control \\
\hline $\begin{array}{l}\text { Labor induction (\%) } \\
\begin{array}{l}\text { Induction due to } \\
\text { fetal indications (\%) }\end{array}\end{array}$ & 40.90 & $35.18 \cdot$ \\
$\begin{array}{l}\text { Cesarean section (\%) } \\
\text { Cesarean section due } \\
\text { to fetal distress (\%) }\end{array}$ & 50 & 47.35. \\
\hline
\end{tabular}

$\cdot \mathrm{p}=\mathrm{NS}$

Table IV. Perinatal Course

\begin{tabular}{llll}
\hline Group & \multicolumn{2}{l}{ Treatment } & \multicolumn{2}{c}{$\begin{array}{l}\text { Control } \\
\mathrm{n}(\%)\end{array}$} & $\mathrm{n}(\%)$ \\
\hline $\begin{array}{l}\text { Intralabor } \\
\text { fetal distress } \\
\text { pH of umbilical } \\
\quad \text { artery }<7.20\end{array}$ & 9 & $(20.45)$ & $7(12.96) \cdot$ \\
$\begin{array}{l}\text { pH of IUGR umbilical } \\
\quad \text { artery < } 7.20\end{array}$ & 3 & $(6.82)$ & $10(18.52) \cdot$ \\
\begin{tabular}{l} 
Mortality \\
\hline
\end{tabular} & 4 & $\begin{array}{l}(9.09) \\
(0)^{+}\end{array}$ & $\begin{array}{c}17(31.48) \\
2(37)^{+}\end{array}$ \\
\hline
\end{tabular}

$\cdot \mathrm{p}=\mathrm{NS}+(\%)$
The group under study demonstrated rate of $6.82 \%$ pathological $\mathrm{pH}$ values in the umbilical artery, while the rate of abnormal values in the control group was $18.52 \%$. In both groups, the greatest percentage of acidotic $\mathrm{pH}$ values was found in the IGR cases. Considering these data more closely we observed that IGR cases receiving b-mimetic treatment showed a rate of $9.09 \%$, while the incidence of low $\mathrm{pH}$ values was $31.48 \%$ in the control group. In spite of the values, the difference is not statistically significant (table IV).

Perinatal mortality was $0 \%$ in the treatment group and $37 \%$ in the control group, the latter is due to two deaths: 1 antepartum death due to an umbilical cord knot and 1 postpartum death due to sepsis. These deaths may not be attributed to fetal growth retardation, poor management of fetal status or lack of administration of vasodilator drugs.

\section{Discussion}

A prolonged hospital stay has been considered a potentially positive factor in the treatment of IGR since this permits closer observation of the mother and fetus. On one hand, the hospitalized patient eats more once better diet than would be expected at home, and likewise, the frequency of surveillance of fetal well-being is increased (FHR/12 hours, NST/48 hours, etc.), thus reducing the time between them.

In our series we did not find any differences in the weight of newborns or in the perinatal outcome results between hospitalized patients and those who remained at home with self-evaluation of fetal movements following a reactive non stress test.

The antepartum fetal death due to a knot in the umbilical cord may not be atributed to a reduced frequency of NST performed since this is an acute obstetric accident which may coexist with a reactive pattern only a few hours earlier. In a review of 19 series published in the literature [6] on the incidence of false reactive NSTs (a false reactive NST means that fetal death took place within 7 days of obtaining a positive result), we found 62 fetal deaths from a total of 14976 (incidence of false reactives $0.41 \%$ ). The cause of death was specifically mentioned in 26 fetal deaths, 11 of which $(42 \%)$ were associated with umbilical cord problems.

With regard to B-mimetic drug therapy, their hypothetical beneficial effect on fetal growth may be deduced from their effects at different levels: In 
the first place, it induces an increase in plasma blood sugar in the maternal curculation [3, 12], and an increase in the heart volume per minute, leading to an increase in uterine blood flow [10].

Thus, an increased blood flow is available to the intervillious space, with a consequent increase in $\mathrm{O}_{2}$ and other elements, especially glucose, which was previously increased [5].

At the level of the placenta, a vasodilatation of villious capillaries was seen [11], with an improved fetal blood transport capacity, suggesting an improved exchange and greater supply of energetic substances. Finally, an increase in circulating glucose was seen at the fetal level [3], possibly due to different mechanisms. On the one hand, diffusion of a greater amount of glucose from the mother to the fetus, a finding we mentioned already, and on the other hand, the direct effect of B-mimetic drugs on the fetus.

These hypothetical beneficial effects of Beta-agonists, do not seem to have a clear clinical expression unless they are administered orally in low doses. In a multicenter study carried out in 1972 by THIERY et al. [13], which assessed the effects that B-mimetic drugs had on premature labor, it was observed that newborns of mothers treated with these agents weighted more than newborns of mothers receiving a placebo.

The observations carried out by Merkatz et al. [9] and FALK LARSON et al. [7] disagree with them. The latter authors, in a study similar to THIERY's, noticed that although the weight of newborns of treated mothers was somewhat higher (97 gm.) than those of non-treated mothers, the difference between groups was not statistically significant. Likewise, in our series, newborns of mothers receiving treatment weighed $17 \mathrm{gm}$. more than newborns from mothers in the control group, and this finding lacks statistical significance.

In summary, we do not feel that prolonged hospital stay with oral ritodrine administration has demonstrated any utility in the treatment of IGR of unknown etiology - not even as symptomatic measures.

Research in this field most likely will concentrate on establishing the etiopathogenity of IGR. Only a deep knowledge of the factors which cause an interruption or retardation of the intrauterine fetal growth process may bring about an efficient treatment.

\section{Summary}

A group of 98 third trimester pregnant women whose ultrasonographic studies raised the suspicion of intrauterine fetal growth retardation was studied. The patients were randomly assigned to two groups: Group A (Treatment group: 44 patients) and Group B (Control group: 54 patients).

All patients were admitted to the hospital upon diagnosis for baseline evaluation. Those in Group A remained in the hospital until delivery (mean stay $15 \pm 5$ days) and received treatment with $10 \mathrm{mg} / \mathrm{t}$.i.d. of p.o. ritodrine. Group B patients were discharged after an average stay of $7 \pm 3$ days. This group was not treated with ritodrine, and they were seen weekly in an outpatient setting. The prevalence of low-birth-weight infants for their gestational age was $47.73 \%$ in the treatment group and $40.74 \%$ in the control group. Of the deliveries in the treatment group, $40.9 \%$ were induced (half for fetal indications). In the control group $35.18 \%$ of the induced

labors was $(47.35 \%$ for fetal indications). Of the cases in the treatment group $18.18 \%$ were delivered by cesarean section, of which $62.5 \%$ were performed for fetal distress. The control group showed similar figures: $16.66 \%$ cesarean sections with $77.7 \%$ of them done for fetal distress. We observed an incidence of $20.45 \%$ of acute fetal distress in the study group against $12.96 \%$ in the control group. Such a difference is not statistically significant. The group under study demonstrated a rate of $6.82 \%$ pathological $\mathrm{pH}$ value in the umbilical artery, while the rate of abnormal values in the control group was $18.52 \%$. In both groups, the greatest percentage of acidotic $\mathrm{pH}$ was observed in patients with IGR.

From these results we cannot infere any advantage of prolonged hospital stay with oral ritodrine administration in the treatment of intrauterine fetal growth retardation of unknown etiology.

Keywords: Intrauterine growth retardation, long term hospital stay, ritodrine.

\section{Zusammenfassung}

Langzeithospitalisierung und Betamimetika bei der Behandlung der intrauterinen Wachstumsretardierung unbekannter Ätiologie
Wir untersuchten 98 Frauen im letzten Schwangerschaftstrimester, bei denen ultrasonographisch der Verdacht auf eine intrauterine Wachstumsretardierung 
(IUGR) erhoben wurde. Nach Randomisierung wurden zwei Gruppen gebildet: Gruppe A stellte mit 44 Patienten die therapierte Gruppe dar, in der Kontrollgruppe B befanden sich 54 Patienten.

Alle Patientinnen wurden nach der Verdachtsdiagnose einer Basisuntersuchung unterzogen. Die Frauen der Gruppe A blieben bis zur Entbidnung im Krankenhaus (mittlerer Aufenthalt $15 \pm 5$ Tage) und erhielten $3 \times 10$ mg Ritodrin/d. Patientinnen der Gruppe B wurden nach durchschnittlich $7 \pm 3$ Tagen entlassen und nicht mit Ritodrin behandelt. Es erfolgten wöchentlich ambulante Kontrollen.

Small-for-date-Kinder traten mit einer Prävalenz von $47,73 \%$ in Gruppe A bzw. von 40,74\% in Gruppe B auf. In Gruppe A wurden 40,9\% der Geburten eingeleitet (davon 50\% aus fetaler Indikation), in Gruppe B 35,18\% (zu 47,35\% aus fetaler Indikation). In Gruppe A betrug die Sektiorate 18,18\%, davon gingen $62,5 \%$ auf ein fetales Distress zurück. Die Kontrollgruppe liefert ähnliche Zahlen: $16,66 \%$ Sektiorate, davon $77,7 \%$ wegen fetalem Distress. Ein akuter fetaler Distress wurde in Gruppe $A$ in $20,45 \%$ der Fälle beobachtet, während es in der Kontrollgruppe bei $12,96 \%$ auftrat. Dieser Unterschied ist statistisch nicht signifikant. In der Gruppe A traten pathologische $\mathrm{pH}$-Werte in der Umbilikalarterie in $6,82 \%$ der Fälle auf, während in der Kontrollgruppe bei $18,52 \%$ abnorme $\mathrm{pH}$-Werte gemessen wurden. In beiden Gruppen waren azidotische Werte gehäuft, wenn tatsächlich eine IUGR vorlag.

Unsere Ergebnisse zeigen, daß die Langzeithospitalisierung und orale Ritodringabe bei der Behandlung der IUGR unbekannter Ätiologie keine Vorteile bzw. Verbesserungen liefern.

Schlüsselwörter: Intrauterine Wachstsumsretardierung, Langzeithospitalisierung, Ritodrin.

\section{Résumé}

\section{Hospitalisation prolongée et betaminetiques dans le trai- tement des retards de la croissance intra-uterins d'etiologie inconnue}

On a étudié un groupe de 98 femmes enceintes au cours du troisième trimestre de leur grossesse, chez lesquelles les échographies avaient fait suspecter un retard de croissance intra-utérin. Les patientes ont été réparties en deux groupes différents par randonisation:

- groupe A: groupe traité $=44$ patientes

- groupe B: groupe contrôle $=54$ patientes

Toutes les patientes ont été hospitalisées dès le diagnostic pour une évaluation de base. Celles du groupe $A$ sont restées hospitalisées jusqu'à l'accouchement (durée moyenne du séjour $15 \pm 5$ jours) et ont reçu un traitement de $10 \mathrm{mg} / \mathrm{t}$. i.d. de ritodrine per 05 . Les patientes du groupe $B$ sont sorties après un séjour moyen de $7 \pm 3$ jours, ce groupe n'avait pas de ritodrine et était controlé hebdommadairement en ambulatoire.

La prévalence des enfants de faible poids de naissance pour l'âge gestationnel a été de $47,73 \%$ dans le groupe traité et de $40,74 \%$ dans le groupe controle.
Dans le groupe traité $40,9 \%$ des accouchements ont été déclenchés ( $50 \%$ pour causes fotales), alors que dans le groupe B ily a eu $35,18 \%$ de déclenchés $(47,35 \%$ pour indication fotale).

$18,18 \%$ des patientes du groupe traité ont eu une césarienne, parmi lesquels $62,5 \%$ pour souffrance fotale. Le groupe contrôle est similaire: $16,66 \%$ de césariennes avec $77,7 \%$ secondaires à une souffrance fœtale.

Nous avons observé une incidence de $20,45 \%$ de souffrance fœtale aïgue dansle groupe traité contre 12,95 dans le groupe controle. Cette différence n'est pas statistiquement significative. Le groupe traité a présenté un taux de $6,82 \%$ de $\mathrm{pH}$ dans l'artère ombilicale pathologiques, alors que le taux de valeurs anormales dans le groupe controle était de $18,52 \%$.

Dans les deux groupes le pourcentage le plus élevé de $\mathrm{pH}$ acidotique a été observé dans les RCIU.

A partir de ces résultats, nous ne pouvons tirer d'avantages à l'hospitalisation prolongée et à la prise de ritodrine pour le traitement du retard de croissance intrautérin sans caluse connuc

Mots-clés: Hospitalisation de longue durée, retard de croissance intra-utérin, ritodrine.

\section{References}

[1] Adelantado JM, mT Auson, L Cabero, Mi EsCribano, A Cabero, C Segur: Peso de los recién nacidos de madre diabética y su relación con la curva de normalidad. Clin Invest Gin Obst 7 (1980) 183

[2] CABERo L: Retardo de cremimiento intrauterino. III. Clin Invest Gin Obst 5 (1976) 122

[3] Cabero L, P Viscasillas, A Roses, M Quilez, R Riera, P Duran Sanchez, J Esteban-Altirriba: Efecto de la infusión de una droga betamimética (ritodrine) a la madre sobre los niveles sanguineos maternos y fetales de glucosa. Clin Invest Gin Obst 2 (1975) 15

[4] CREASY RK, R RESNIK: Intrauterine growth retardation. In: CREASY, RK and R RESNIK (eds): Maternal fetal medicine. W. B. Saunders Company. Philadelphia 1984

[5] Duran Sanchez P: Mecanismos de acción de los fármacos betamiméticos en obstetricia. In: EsTEBAN-Altirriba J and P Duran SANChez (eds): Perinatología Clínica I. Salvat Barcelona 1977 
[6] FABRE E: Monitorización biofísica no estresante. In: Procceedings of the VI Reunión de Medicina Perinatal Barcelona 1984

[7] Falk Larsen J, K Eldon, AP Lange, M Leegard, M OSLER, J SEDERBERG OSLER, M PERMIN: Ritodrine in the treatment of preterm labor: Second Danish multicenter study. Obstet Gynecol 67 (1986) 607

[8] Lin ChIN-Chu, MI Evans: Antepartum management. In: McGraw-Hill Book Company (eds): Intrauterine growth retardation: pathophysiology and clinical management. New York 1984

[9] Merkatz IR, JB Peter, TP BARDen: Ritodrine hydrochloride: $\mathrm{A}$ betamimetic agent for use in preterm labor. Evidence of efficacy. Obstet Gynecol 56 (1980) 7

[10] Renaud R, P Brettes, M Irrmann, G Boog, J SCHUMACHER, R GANDAR: A double-blind crossover trial to assess the effect of ritodrine on uterine blood flow in normal and pathologic pregnancies. A preliminary report. In: Baumgarten $\mathrm{K}, \mathrm{A}$ WeSELIUS DE CASPARIS (eds): Proceedings of International Symposium on the treatment of fetal risks Baden 1972

[11] Santana M, E Giralt, L Cabero, J EstebanAltiRRIBA: Efecto de los fármacos beta-miméticos sobre las vellosidades de la placenta humana. In: Esteban-AltirRiba J and P. Duran SANChez (eds): Perinatología Clínica I. Salvat Barcelona 1977
[12] Spellacy WN, AC Cruz, WC BuHI, SA Birk: The acute effects of ritodrine infusion on maternal metabolism: 8 Measurements of levels of glucose, insulin, glucagon, triglycerides, cholesterol, placental lactogen, and chorionic gonadotropin. Am J Obstet Gynecol 131 (1978) 637

[13] Thiery M, K Baumgarten, L Brosens, J EstebanAltirriba, O Gamissans, A Yo Le Sian, M FlynN, $R$ VAN STRIK: A multicentre trial with ritodrine in the treatment of premature labour in patients with intact membranes. In: BAUMGARTEN $\mathrm{K}$, A WesSELIUS DE CASPARIS (eds): Proceedings of the International Symposium on the treatment of fetal risk Baden 1972

Received August 31, 1987. Revised January 1, 1988. Accepted March 3, 1988.

Dr. L. Cabero

Servicio de Obstetricia y Ginecologia Hospital de la Santa Creu i Sant Pau S. Antoni M. Claret 167 08025 Barcelona

España 